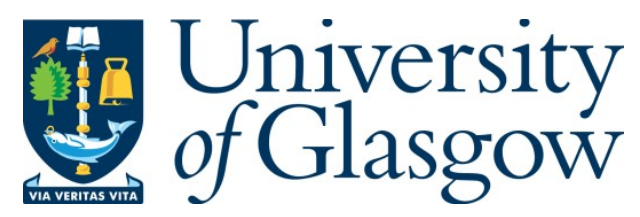

Syrotinski, M. (2019) Postcolonial untranslatability: reading Achille Mbembe with Barbara Cassin. Journal of Postcolonial Writing, 55(6), pp. 850-862.

(doi: 10.1080/17449855.2019.1681192)

This is the Author Accepted Manuscript.

There may be differences between this version and the published version. You are advised to consult the publisher's version if you wish to cite from it.

https://eprints.gla.ac.uk/194161/

Deposited on: 30 August 2019

Enlighten - Research publications by members of the University of Glasgow http://eprints.gla.ac.uk 
Michael Syrotinski

Marshall Professor of French, University of Glasgow, UK

Professor Michael Syrotinski

School of Modern Languages and Cultures

Hetherington Building, Bute Gardens

Glasgow, G12 8RS

Scotland, UK

Michael.Syrotinski@gla.ac.uk

ORCID ID: https://orcid.org/0000-0002-5521-8432

Michael Syrotinski is Marshal Professor of French at the University of Glasgow. He has published widely on French philosophy, critical theory, contemporary $20^{\text {th }}$ and $21^{\text {st }}$ century French literature, and Francophone African literature and philosophy within a postcolonial frame of reference. He is author of several books, including Singular Peformances: Reinscribing the Subject in Contemporary Francophone African Writing (Virginia UP, 2002) and Deconstruction and the Postcolonial (Liverpool UP, 2007). He is one of the main translators of the recent Anglophone edition of Barbara Cassin's Dictionary of Untranslatables (Princeton UP, 2014). 


\title{
Postcolonial Untranslatability: Reading Achille Mbembe with Barbara Cassin
}

\author{
Michael Syrotinski \\ University of Glasgow
}

Barbara Cassin's monumental Dictionary of Untranslatables, first published in French in 2004, is an encyclopedic dictionary of nearly 400 philosophical, literary, aesthetic and political terms which have had a long-lasting impact on thinking across the humanities. Translation is central to any consideration of diasporic linguistic border crossing, and the "Untranslatable" (those words or terms which locate problems of translatability at the heart of contemporary critical theory) has opened up new approaches to philosophically informed Translation Studies. This article argues that there is a far-reaching resonance between Barbara Cassin's Dictionary of Untranslatables project and Achille Mbembe's theorization of the postcolonial, precisely insofar as they meet at the crossroads of (un)translatability. Both texts are read performatively, in terms of their respective writing practices and theoretical "entanglements", one of Mbembe's key terms.

Keywords: untranslatable; multilingual; decolonization; globalization; nègre; world. 


\section{Postcolonial Untranslatability: Reading Achille Mbembe with Barbara Cassin}

Translation is at the heart of any reflection on diasporic linguistic border crossing. The point of departure and hypothesis of this article is that the question of "untranslatability", as theorized most extensively by Barbara Cassin, can be read as pivotal to the thinking and writing of Achille Mbembe. In his excellent translation and edition of Mbembe's Critique de la raison nègre [Critique of Black Reason] (Mbembe 2017), Laurent Dubois comments on the difficulty of translating the French "nègre" in a way that preserves and fully references its long history of negative accretions, from classical times through the many forms of enduring racism that still plague the world today. As Dubois puts it:

Translating "nègre” itself requires a strategy consonant with Mbembe’s own. Here, the unity of "le Nègre" becomes a trinity of words: sometimes "Blacks", sometimes "Blackness", and at others, "The Black Man". This allowed me to map, in particular, correspondences that moved from the multiplicity of meanings in the French term to words that pointed and flowed well in English. (Mbembe 2017, xiv).

He goes on to underline "how central it is to the very constitution of modern thought, politics, ideology, and social life.” (xv)

Mbembe's text, no doubt echoing Gayatri Spivak's Critique of Postcolonial Reason (Spivak 1999), is provocatively and deliberately oxymoronic in talking about "black reason", since it speaks to, and powerfully challenges, the entire history of the exclusion of the racially denigrated or dehumanized other from Western reason or logos, and thus its simultaneous exclusion from different philosophical accounts of subjectivity and agency, from the Enlightenment onwards. Mbembe's central thesis is that "reason" is from the outset founded 
on a constitutive exclusion of "nègre", and as Frantz Fanon himself bore witness in Black Skin, White Masks in his account of the experience of the "nègre", he or she is from this perspective a nothing, or not a thing, or less than a thing, in philosophical as well as political terms (Fanon 2008). At the same time, Mbembe's focus on the philological, philosophical, political, legal, and psychosocial history and use of the terms "Africa" and "nègre" closely aligns his approach with Barbara Cassin's Untranslatables project, in particular the second chapter of The Critique of Black Reason, "The Well of Fantasies", which as a richly informed archeological narrative could easily be an additional entry in itself to a Dictionary of Untranslatables, but the omission of which from the original French edition might at first appear to be a significant and symptomatic one. The question of the "Untranslatable" (those words or terms which locate problems of translatability at the heart of contemporary critical theory, or philosophizing "in languages" in the plural, as Cassin puts it) has opened up new paradigms for a philosophically informed approaches to translation. Cassin's monumental Dictionary of Untranslatables, first published in French in 2004 as Vocabulaire européen des philosophies, is now being translated into several new language editions, which have shifted and re-energized the entire project in important ways (Cassin 2004, 2014). I will return later on to these questions of re-translation and of symptomatic exclusion, and what I will argue is that there is in fact a more far-reaching and deeper resonance between Mbembe's and Cassin's respective projects, precisely insofar as they meet at the crossroads of (un)translatability. My specific approach will be to read both texts performatively, in terms of their respective writing practices and theoretical "entanglements", itself one of Mbembe's key terms. 


\section{Colonialism, Multilingualism and the Untranslatable}

Monolingualism has long been seen by postcolonial theorists as one of the main weapons used to assert and enforce the assimiliationist politics and ideology of colonialism, and in particular its role in the European civilizing "missions" which validated the age of high Empire in the nineteenth and twentieth centuries, In a public lecture he delivered in Johannesburg in 2015, later published as an article (Mbembe 2016), Mbembe intervened in the increasingly widespread debates around the decolonizing of the University curriculum, as epitomized by the "Rhodes Must Fall" and other similar decolonial movements. After discussing Fanon's trenchant critique of misguided neo-colonial forms of Africanization during the early years of Independence, he turns to a discussion of the politics of language, as articulated most forcefully by the Kenyan writer Ngugi wa Thiong'o in his famous text Decolonizing the Mind (Thiong'o 1986), in which the latter makes an impassioned plea for literature produced in African rather than in colonial languages, just as he himself writes and publishes in Gikuyu, even if this radically limits his potential readership. As Mbembe notes:

Colonialism rhymes with mono-lingualism. The African university of tomorrow will be multilingual. It will teach (in) Swahili, isiZulu, isiXhosa, Shona, Yoruba, Hausa, Lingala, Gikuyu and it will teach all those other African languages French, Portuguese or Arabic have become while making a space for Chinese, Hindu etc. It will turn these languages into a creative repository of concepts originating from the four corners of the Earth. (Mbembe 2016, 35. My emphasis).

So French, Portuguese and Arabic, all colonial languages in Africa, have themselves been appropriated and assimilated by African languages, and are no longer the languages of colonial command and control they once were. Mbembe sees a certain inevitability in this process, and it leads him to formulate a necessary link between the kind of recasting of 
disciplinary formations that a decolonized curriculum would entail, and a defiantly pluralistic approach to the languages in which those disciplines are studied and taught. This rethinking of the university would involve a concomitant rethinking of universalism:

Whatever the case, there is a recognition of the exhaustion of the present academic model with its origins in the universalism of the Enlightenment. Boaventura de Sousa or Enrique Dussel for instance make it clear that knowledge can only be thought of as universal if it is by definition pluriversal. They have also made it clear that at the end of the decolonizing process, we will no longer have a university. We will have a pluriversity. (36. My emphasis).

This advocacy of a new "pluriversity" echoes his emphasis elsewhere, in talking about postcolonial Africa, on the adoption of a more global, cosomopolitan perspective: "To decolonize the university is therefore to reform it with the aim of creating a less provincial and more open critical cosmopolitan pluriversalism." (37).

Barbara Cassin has of course theorized more overtly, and at greater length, this complex relationship between language and universalism. This is indeed the main focus of her recent volume Eloge de la traduction: Compliquer l'universel [In Praise of Translation: Complicating the Universal. Cassin 2016], in which she underlines how the Untranslatables as a project radically challenges linguistic imperialism in all its forms, most notably the spread of lowest common denominator forms of language use in global communications, such as global English, or "globish", and the claims to universalism it carries with it (Cassin 2016, 27-86, 216). Cassin make explicit reference to Mbembe's Critique of Black Reason tangentially towards the end of her book, in an epilogue reflecting on the global migrant crisis, and noting the importance of Mbembe's argument about the urgent need for "counterimaginary", even utopian discourses, to contest the sombre turn taken by international politics 
in recent times. Although Mbembe is certainly not one of Cassin's major or even minor interlocutors in the way that, for example, Alain Badiou, or Jacques Lacan, or Hannah Arendt, or Greek philosophers more generally are for her, their projects could be said to meet and enter into productive critical dialogue around the "in-betweenness" both of a plurilingual philosophizing and of a postcolonial form of cosomopolitanism. As she says:

It was then that the other "between" of "between-two" [l'entre-deux] presented itself to me as a "counter-imaginary", the very one whose necessity Achille Mbembe invoked. No common world without an appetite for what is "between" [...] This is how Achille Mbembe ends an interview he gave to Libération presenting his Critique of Black Reason: "We could begin by demanding the right for any human being to reside wherever he or she wished to." (230. My translation).

Cassin notes that this is perhaps a utopian demand, but that is precisely the point here. Mbembe continues, as quoted by Cassin: "It is at any rate essential to formulate a counterimaginary [un contre-imaginaire] to oppose this insane imaginary of a society with no foreigners or outsiders [une société sans étrangers].” (230). What I am suggesting is that this crossing of paths between Cassin and Mbembe should come as no surprise, given that her notion of "complicating universalism(s)" informs the strong counter-discursive force of much postcolonial theory more generally, in which Mbembe has become a major presence, and his foregrounding of the more utopian imagination at the heart of the anti-colonial texts not only of Fanon, but also of Leopold Senghor, demonstrates clearly where his political sympathies lie. Inversely, I will argue, it is Cassin's critique of universalism through the vector of translation that accompanies a critical movement away from and beyond the alleged philosophical Eurocentrism of the original Vocabulaire européen des philosophies towards more global, decolonial concerns. 


\section{What's in a Wor(l)d?}

How better to approach the question of the World as it relates to Cassin's defiantly plurilingual approach to the truth, the logos of Western reason, than by looking first of all at the entry for "World" in the Dictionary of Untranslatables ("Monde" in the original French)? This will allow us to begin to unpack the global in globalization, and explore how it differs from the monde in mondialisation, or Welt in German within the context of long tradition of idealist philosophy. Perhaps unsurprisingly, this word is one of the short "signpost" entries Cassin terms "directionals", which are those excessively wide and all-encompassing keywords it would be impossible to do justice to in the space of a single article, so they function to guide the reader towards different connotations and semantic nuances of the term unpacked in more detail elsewhere in the Dictionary of Untranslatables. Given the primarily European orientation of the original Vocabulaire, one key reference point is the Russian ("mir" as both world and peace), and the German, particularly Kant's division between a cosmological meaning (mundus as universe) and an anthropological meaning. Cassin then breaks it down into finer distinctions: the natural world in the broadest sense of the term (which takes us to the entry for "Nature"); ontological and sociological definitions (considered in the context of "Welt"); theological histories of the term (under "Secular", and what it means to "come into the world"); chronological distinctions (within reference to "Time" and "Historia Universalis"); and finally, the more contemporary context of existential or mundane experience (cross-referenced in "Dasein"). 
The perspectival shift from monde to world in the Anglophone edition of the Vocabulaire sets the tone for what will in effect become a series of new afterlives for the project. Conscious of their North American readership and the theoretical contexts familiar to them, including the postcolonial, the editors of the Dictionary of Untranslatables also commissioned several new contributions that brought out these resonances more explicitly, and these included additional entries by, for example, Gayatri Spivak ("Planetarity"), and Robert Young (“Colonia and Imperium”). As Young points out in his history of the terms colonia and imperium, these are words whose meanings are transformed over time as they are translated and passed from one culture and political system to another. Thus coloniae was originally the Latin name for far-flung Roman imperial garrisons, and the term used to translate the Greek apoikia. Since the function of coloniae as strategic outposts was so particular to the Roman Empire, Greeks did not subsequently translate the word back the other way, but themselves simply adopted the Latin colonia, which Young points to for this reason as an untranslatable term: kolonia. It was this untranslatable word that subsequently made its way into the French language in the fourteenth century, and then English in the sixteenth century, to describe overseas plantations and settlements. So although it initially had quite positive connotations when referring to systems established during Roman imperial times, "colonialism" as it was practiced by the English and French in the nineteenth and twentieth centuries led to the negative associations it has nowadays, as a mode of exploitation of subaltern nations by European imperial powers. (Cassin 2014, 1057).

If the English language version of the Dictionary of Untranslatables gestures towards a postcolonial perspective that was perhaps symptomatically missing from the original French, the link between translation and colonial critique has increasingly come 
to the fore with subsequent translations and editions of the French original. There are now a growing number of different language versions either complete or on the way: besides the Dictionary of Untranslatables, there are Ukrainian and Russian language editions, a Romanian one, a Portuguese translation (based in Brazil), and a Spanish one (based in Mexico), as well as an online Italian version, and translations into Hebrew and Arabic of several entries. Given that the shift away from the European base towards a more global perspective has meant a certain "de-westernisation" of philosophy, and a questioning of the national and cultural hierarchies that have held sway traditionally, the editorial centres of the Portuguese and Hispanic editions were strategically located in former colonial countries for this very reason. To further emphasize the extent to which this was not merely an abstract, philosophical consideration, in a project that came out of Cassin's long-standing interest in African culture, she brought together a number of distinguished Africanists in a collaborative initiative, with the objective of questioning the underlying linguistic prejudices governing UNESCO's conventions on "World Heritage." This was for her all the more compelling, given the recent semantic expansion of the term to include examples of intangible heritage, as well as natural and cultural heritages: in other words, what properly "belongs" to a nation, and how nations define and lay claim to this "property". Their starting point was that the criteria for eligibility were essentially based on decisions reached by UNESCO and European bodies without reference to alternative traditions, or without thinking through the complex and fluid relations between heritage, territory, history, memory and identity: in short, overlooking the fact that conceptions of heritage vary depending on the place, time, and linguistic universe in which they are formed. Several workshops were organized, exploring the range of possible connections and translations between French, English, and several African languages (the Fula, Bambara, Swahili, Sukuma and 
Tsonga language families), with different languages articulating different ways speakers see the world, and thus how they interpret what constitutes their heritage. The focus of their discussions was on two words: heritage, and museum, and the resulting volume, Les intraduisibles du patrimoine en Afrique subsaharienne [Heritage Untranslatables in Sub-Saharan Africa] was itself a perfomative example of Untranslatability in action, with seven sections translated from and into each of the languages explored (Cassin and Wozny 2014). Problems of translation, including between African languages, but also interlingual borrowings, betrayals, mistranslations, shortcuts and detours all come into play. As a consequence, UNESCO was made to reflect on its own universalist assumptions, and it helped to re-energize the dialogue between UNESCO and Africa. This plurilingual approach to heritage thereby enabled a very different relationship between language and political power, a more democratic negotiation of meaning, which in turn required letting go of a certain linguistic imperialism, however unconscious or unintentional that may be.

The African philosopher Souleymane Bachir Diagne, one of the additional contributors to the Dictionary of Untranslatables, has argued for the need to retain yet challenge from within the notion of univeralism, stressing the value of Cassin's approach for African philosophy and language. For him, it is a question of complicating the universal and not rejecting it, precisely because it is complicated (Diagne, in Büttgen, Gendreau-Massaloux, North eds. 243). He borrows the term "universel latéral” [lateral universal] from Merleau- Ponty, who uses it to discuss the process whereby anthropology or ethnology experience universalism, phenomenologically speaking, in an endlessly differentiated and "lateral", or "transversal", process of exposure to the other. So the first stage for African philosophy is to challenge Western rationality and its complicity with the colonial, imperial 
mission, and to this end Diagne invokes a number of African philosophers, such as Alexis Kagame, who philosophizes in his native Rwandan language, Kinyarwanda, in an attempt to reclaim subjectivity, agency, and indeed an entire African ontology. However, this runs the risk, for Diagne, of falling into the same trap of ontological essentialism or nationalism that Cassin's entire Untranslatables project works to resist counter-discursively. Diagne thus argues for a more relativized, non-ontological, and non-national approach to the problematic notion itself of "African philosophy", and points precisely towards the kind of multilingual project that the Dictionary of Untranslatables represents, and which resonates strongly with Mbembe's discussion of decolonizing knowledge production in the university.

\section{Writing Africa/Philosophizing in Languages: Mbembe's and Cassin's Performances}

The problem of how to reaffirm agency and subjectivity within the language of the colonizer or within philosophical traditions where this agency has been constitutionally negated or excluded is of course a familiar dilemma in postcolonial studies. So, for example, Spivak's Critique of Postcolonial Reason (Spivak 1999) looks at infrequently visited corners of the texts of the majors figures of the Western philosophical Enlightenment in order to tease out the complicity between the imperial underpinning of European philosophies of the subject and various forms of colonized thinking, which are often merely masquerading as universalism. The challenge for formerly colonized African writers and thinkers becomes the extent to which they are able, within an adopted language and intellectual heritage, to "step outside" of this history, a problem articulated most cogently by V. Y. Mudimbe in The Invention of 
Africa. (Mudimbe 1994). Achille Mbembe, in On the Postcolony, also argues for the need to escape the "bonds of subjection" of European colonialism in Africa. In the chapter entitled "Of Commandement" (one of his terms he reinvests with new meaning), Mbembe traces the corruption and violence that still characterize many African postcolonial regimes back to the "founding violence" of the act of imperial conquest. Postcolonial regimes have in his view inherited the same unwritten colonial laws of impunity and violence, sustained through a continued denigration of the native population as less than human (Mbembe 2001, 24-65). This domination and represssion takes an economic form to be sure, but Mbembe argues that commandement works perhaps even more powerfully at an imaginary and corporeal level, so he stresses the need to bring the body back into the question of the subject. Inspired by the work of Jean-Luc Nancy, he goes back to Descartes, although in a way that reconceptualizes Descartes, or one might even say Africanizes, and “postcolonizes” Descartes.

As early as Afriques Indociles, Mbembe's study of the misunderstood nature of Christianity in its relation to political power in the postcolonial African state, he was already challenging what was becoming something of a critical orthodoxy, that is, the assumed tight complicity between Christian missions and the more generalized “civilizing mission" of the high colonial era (Mbembe 1988),. He goes against the grain of this orthodoxy by reading such overarching narratives as part of a long metaphysical tradition, more precisely Western Christian logocentrism - which Derrida very cleverly combined in his neologism "globalatinization" (Derrida 2002) -- that was in reality recycled, reused, and readapted by African appropriations of Christianity. In other words, Africans were anything but "docile" subjects in this process. This attention to a performative reappropriation of colonial power, and a politically activist assertion of agency, also underpins Mbembe's long commitment to revolutionary figures such as 
Ruben Um Nyobè, the founder of the militant anti-colonialist UPC in Cameroon who was assassinated by the French in 1958, and Frantz Fanon, whose complete works Mbembe recently re-edited (Fanon 2011), and whose influence on Mbembe's thinking seems to become ever more central. It is clear, then, that there is strong guiding thread, from his early sociological analyses, through On the Postcolony, to his more recent polemical interventions.

In the preface to the French re-edition of De la Postcolonie (Mbembe 2005), Mbembe spends some time reflecting on the reception history this groundbreaking volume has had, and in a rather telling moment, he offers us something of a guide to his work as a whole, and which I would like to quote at length because it frames so well the second half of this article. This is how he summarizes his approach:

[...] in contrast to the usual approach adopted in postcolonial theory, my aim in challenging the solipsistic nature of the Western logos was to pave the way for a critique of the subject and to rethink the meaning of responsibility.

I still needed to find a way to express what this experience of responsibility [cette épreuve de la responsabilité] involved and a language to take its pulse. Confronted by the absurd nature of most discourses about the African continent, it seemed to me that one way to break free from this straightjacket was to experiment with language, and try first of all to blow it up [tenter de la dynamiter]. I tried to achieve this work of demolition through shortcuts, repetitions, inventions, a form of narration that used memories and digression as much as it did sentences that tried to be clear, "scientific", and to follow each other sequentially. My "writing of Africa" [mon écriture de l'Afrique] would at times be open, at other times hermetic, made up of rhythms, melodies, sounds, a 
certain music, much like a "song of the shadow" [chant d'ombre] by Senghor, which requires not just hearing, but all the senses to comprehend it fully. I was searching for a writing that could lead the reader to an encounter with his or her own senses. But these encounters only interest me insofar as they are fragmentary, evanescent, chopped up, sometimes missed. What I am interested in are encounters with those zones that are overloaded with memory and with the African present, and with areas of knowledge that are not traditionally part of the social sciences : philosophy, the arts, music, religion, literature, psychoanalysis. (Mbembe 2005, xvii. My translation).

What runs through this account of his intellectual trajectory is first of all the critical distance he takes from both "postcolonial theory" (he prefers the term "thought"), and traditional social sciences. Secondly, like Cassin but differently, his objective will be to critique the claims logos makes to anchor Western reason in all its forms, including that of the philosophical subject. He questions what it means to think and act "responsibly", and part of that responsibility will be to rethink the relation between body and subject, to take the "pulse" of this body. This will ultimately require a very different mode and style of writing Africa, and thus of self-writing, as well as a deliberate exposure to creative expression in its more experimental forms. Indeed, this was the impetus behind a major conference Mbembe co-organized in Dakar and St. Louis in 2016, bringing together African artists and intellectuals, and subsequently published as Ecrire l'Afrique-Monde [Writing World-Africa] (Mbembe and Sarr 2017).

Jean-Luc Nancy's post-phenomenological thinking has offered a conceptual framework for Mbembe to broach the question of the "world", and what it might mean for Africa to talk of its “own" world. Mbembe's turn to Nancy is most evident in Sortir 
de la grande nuit [Out of the Dark Night], his openly polemical intervention in the fiftieth anniversary celebrations commemorating "Les Indépendances", or the period of decolonization of most African nations (Mbembe 2010; 2019). This text is from the outset defiantly political, and marks an explicit re-affirmation of Fanon's anti-colonial thinking, although this "return to Fanon" should not have come as a surprise, given that the title is a direct reference to Fanon's famous line from the conclusion of Les Damnés de la terre [The Wretched of the Earth]: 'La grande nuit dans laquelle nous fûmes plongés, il nous faut la secouer et en sortir' (in Richard Philcox's translation "We must shake off the great mantle of night which has enveloped up, and reach for the light" [Fanon 1961; 2004]). In writing this text, Mbembe's gesture is far more than one of militant indignation. In an autobiographical opening chapter - which reprises an earlier autobiographical essay (Mbembe, 1993) - he aligns himself with an anti-colonial genealogy of thinkers and writers such as Ruben Um Nyobè and the liberation theologist Jean-Marc Éla, as well as Fanon. What is intriguing is that "writing Africa" - which in his earlier essay took the form of (re-)writing a rather ambivalent attachment to his home nation, Cameroon, as a "non-place" (non-lieu) -- in 2010 become far more transnational in its scope. This no doubt reflects Mbembe's own personal intellectual trajectory, but also the shift in his writing over the last two decades towards considerations of migration flows between nations within Africa, and in terms of Africa's response to the challenges of contemporary globalization.

At the same time, however, this more stridently political voice is a restatement of the place of the poetic, which appears to owe a good deal to the thinking of Jean-Luc Nancy, particularly insofar as it relates to the meaning of globalization, Europe, decolonization, and the world. Mbembe talks for example of "the poetic productivity of memory and of the religious" (Mbembe 2010, 52) and in the chapter entitled "Dis- 
enclosure of the world and ascent towards humanity" ["Déclosion du monde et montée en humanité"], the key notion that comes to the fore is Nancy's idea of "déclosion $d u$ monde," which Nancy articulates most extensively in his text Déconstruction du christianisme [Deconstruction of Christianity] (Nancy 2005). Mbembe reframes Nancy's concepts in more explicitly political terms (notably his rethinking of world in The Creation of the World (Nancy 2002; 2007), and of community as "being-incommon" ("être-en-commun"). This conjunction of the literary (specifically the poetic) with the philosophical is indeed what allies Mbembe most closely to French thinkers such as Derrida and Nancy, whose thinking is always at the intersection of literature and philosophy, and as I noted earlier on, this is precisely what Cassin's work accomplishes in breaking down the borders between philosophy and its others. To illustrate this, I would like to look briefly at two of the ways in which Mbembe rewrites Nancy in a postcolonial African context.

In The Creation of the World, Nancy makes a distinction between two ways in which one can understand the term "globalization". He underscores the difference between the English term globalization, and its not quite synonymous French equivalent, mondialisation (even though the French translation of his text simply rewrites mondialisation in most instances as globalization). This difference is a crucial one in Nancy's eyes. For him, globalization as represented by the globalized economy, exchange value and capitalist accumulation, is seen as a totalizing movement which conceives of the world according to a logic of "bad infinity" (Nancy 2002; 2009, 38). Nancy opposes this to the world-forming logic of mondialisation -- as he puts it, "the world has lost its capacity to "form a world' [faire monde]" (34) - by which he means a kind of creation "ex nihilo". "Creating a world" thus involves a suspension of every previous representation of the world: "To create the world means: immediately, without 
delay, reopening each possible struggle for a world, that is, for what must form the opposite of a global injustice against a background of general equivalence" (54). In some ways, this can be seen as a reformulation of an earlier opposition which Nancy developed in his The Inoperative Community (1991) between myth (as an allencompassing representation of the world, similar to globalization understood as bad infinity), and literature (which has at its heart an interruptive power that undoes the synthetic unity of myth, and is seen by Nancy as a more fundamental creative act: precisely, the creation of a world).

Literature thus implies a doubling up, engaging with the world while at the same time remaking the world, which I have argued elsewhere takes the form of a reprise, or a "performative reinscription" (Syrotinski 2002). Valentin Mudimbe, in another context, uses the term "reprise" to account for the simultaneous process of interruption, taking up again, and rewriting of African artistic traditions, that also involves a critical self-evaluation: "It thus means the the act of coming back to something that has been interrupted (literally re-prendre) and the assessment of the 'tools' at our disposal, but also to signify a third, interstitial critical reflection between these two meanings." (Mudimbe 1991, 276). This “between-two" echoes Cassin's earlier definition of translation, or untranslatability, and I would argue that Mbembe's "rewriting Africa" involves just such an aesthetic reprise, and is closer to the force of creation one associates with the poetic. Indeed, it is perhaps no accident that African literature, most notably Francophone, has its potent origin in poetic form, and Mbembe's return to the Senghor of the Anthologie de la nouvelle poésie nègre et malgache de langue française marks an important re-reading of a writer and thinker whose poetry has been rather occluded by what many see as the discredited essentialism of Negritude philosophy. 
This brings into focus the second reference: Mbembe's adoption and adaptation of Jean-Luc Nancy’s term “dis-enclosure” (déclosion), a neologism Nancy uses principally to re-read Christian motifs in a number of thinkers and literary traditions, which as we have seen with Afriques indociles is a resonant frame of reference for Mbembe. As Mbembe points out, this term indicates the act of opening up something that is not only closed, but also enclosed, such as an enclosure, so it is a profoundly transformative act, which is at the same time a coming into being, or éclosion (literally: hatching, as a young bird comes into the world). It could be seen as analogous to the creative and transformative difference between globalization and mondialisation in The Creation of the World. As Mbembe puts it: "The idea of déclosion includes that of éclosion, of a sudden appearance, or advent of something new, of an opening out" (Mbembe 2010, 68). The term déclosion functions in Mbembe's text as a paronomastic link-word joining together éclosion, déclosion, and décolonisation, connecting Nancy’s (post-) phenomenological rethinking of being and the world to the radical political anticolonialism of Fanon and his successors (including Mbembe), insofar as decolonization is essentially about reclaiming a world, and one's place within the world. This allows for the possibility of a return to the hidden and perhaps neglected creative political force of the Négritude philosophy of Léopold Sedar Senghor, and particularly his reflection on universalism -- that is, how we can think the specificity of Africa in relation to the question of universal humanism -- which echoes closely Nancy's conceptualization of "being-in-common", whereby he describes the singularity of existence as a necessary relationship of sharing, of partage. This is how Mbembe brings Fanon and Senghor back together:

In his [Nancy's] eyes, this "making common" [mise en commun] is the basis for the rebirth of the world, and the coming of a mixed universal community, 
governed by the principle of a sharing of both differences, and of what is unique, and in this respect, open to the whole. In the case of Fanon as in that of Senghor, we are heirs to the whole world. At the same time the world -- and thus this legacy -- still remain to be created. The world is in creation, as are we too. (Mbembe 2010, 70-71).

The "poetics" of "writing Africa" are thus intimately linked to a strong political agenda for Mbembe, a thinking about the future of Africa in a more global context, which he terms “Afropolitanism":

Afropolitanism is not the same thing as Panafricanism or Negritude.

Afropolitanism is a stylistics and a politics, an aesthetics and a certain poetics of the world. It is a way of being in the world which as a principle refuses any identity as victim (...). It also takes a political and cultural position with respect to the nation, to race, and to the question of difference in general. (Mbembe, 2012. 232).

Déclosion, and the way in which Mbembe puts it to work, might thus mark it as an Untranslatable term, whose effectiveness is only evident once it is read at the level of its linguistic playfulness. It reactivates the lost energy of decolonization, or rather opens the way for Africa to free itself from the continuing legacy of colonialism in all its forms, but at the same time stakes a strong and active claim for its place within the contemporary globalized world. And it is the very act of Mbembe's Writing Africa that to my mind aligns it closely with Cassin's Untranslatables project, with its rich tapestry of layered memories, its assemblages, its neologisms and inventions, its fragmentations, and its insistent and unapologetic repetitions-with-a-difference. 


\section{Fanon's Pharmakon}

What might at first appear a rather speculative linking of Cassin and Mbembe proves, then, to be a much more intricately woven tapestry, which I will only have time to suggest in this concluding section. Mbembe's recent essay Politiques de l'inimité [Politics of Enmity] (Mbembe 2016b), a title that echoes, or perhaps postcolonially rewrites or overwrites, Derrida's Politics of Friendship, just as his Critique of Black Reason does with Spivak's earlier text, continues to mine Fanon's work for the lessons it has to teach us about contemporary global politics, and its many apparently irreconcilable tensions and contradictions. The third chapter of this text Mbembe entitles "La pharmacie de Fanon" [Fanon's Pharmacy], and in it he reminds us, in a powerful account of Fanon's work as a psychiatric doctor, of the depth of his commitment to a compassionate humanism. "Pharmacie" is of course, not only a Pharmacy, a place dedicated to healing human suffering, but it is the translation of the Greek pharmakon, a word, as is more widely known since Derrida's famous essay "Plato's Pharmacy", that means both cure but also its opposite poison, and as such it radically undermines the very foundation of the logocentrism of Aristotle and Plato, for whom logos was an operation of exclusion of its "bad others", including polysemy, homonymy, contradiction, and non-sense. The kind of linguistic equivocation that Derrida highlights becomes for Cassin not merely one aspect among others of language (and by extension, of translation), but its very condition of possibility, in other words a radical ambiguity at the level both of semantics and syntax. This attention to infinite plurality of different meanings, nuances and associations, both within each language but more importantly between languages, is of course the underlying principle of the 
Dictionary of Untranslatables project. In her reading of Jacques Lacan as an equivalent figure to the Greek sophists (Cassin 2012; 2019), she contrasts what she calls their "logology" to the ontology that was seen by Aristotle and Plato as the truth and destiny of serious philosophy. One consequence of this emphasis on logology as opposed to ontology is to relativize the traditional cornerstones of philosophy, such as truth, being, and universalism, and it is in this respect that Cassin's reading of Greek philosophy is so profoundly original, since she demonstrates through an extraordinary attention to philological detail that the Greek sophists - notably Democritus, Gorgias, and Parmenides -- were just as aware as we are of the "play of the signifier", the materiality of the letter, or a kind of performative force within language.

One startling example of this is her discussion towards the end of Jacques le sophiste of a passage from Democritus. Democritus is credited with being the first great theorist of atomism, but his philosophy has often been discredited for its cynical materialism. In reading Democritus's original Greek text, however, Cassin comes across the word "den", a strange bit of a word which does not in fact exist, and never existed, in the Greek language. It is not even the Greek for nothing (mêden), but is less than nothing, or subtracted from nothing. What Democritus does, according to Cassin, is to think through the vast questions of being and nothingness, not metaphysically, but in terms of how nothingness, negation, absence, or subtraction can be expressed, in and through language (Cassin 2012). This negation and exclusion, Mbembe suggests in recalling Fanon's attempts to write his own constitutive nothingness into existence as a Black Man, a nègre, in the famous passage from Black Skin, White Masks, is of exactly the same order.

What, then, would it take not just to be considered as part of the world, but to be part of the world, of the whole world (the "Pan" in "Panafricanism")? In many ways, 
this was the very question Senghor and Fanon were grappling with, and Mbembe suggests that the only way to make up such an existential deficit, the only way back from such radical negation, or subtraction from humanity, is what he terms a "montée en humanité" (Mbembe 2010, 57), which we might translate imperfectly as an "ascent towards humanity", although this may well be another Untranslatable term. This transformative energy of the Untranslatable gestures towards a healing, reparative power of language, that is, language which has the courage to challenge its own monolingual coloniality, and its claims to a misleading universalism. The poison is also the cure: the pharmakon is the rewriting and reclaiming of Africa and nègre, and the African modernity that underpins this will have to be transversally universal, or pluriversal, and well as multilingual, and open to the radical otherness within and between languages. Gary Wilder (2015), in Freedom Time: Negritude, Decolonization and the Future of the World, has written brilliantly about Senghor and Césaire as utopian, counter-imaginary thinkers, and about how important it is to go back and reread their texts in this light at a time of such weak political imagination on a global scale. Wilder finds it hard to reconcile his own re-reading of Senghor with Fanon's dismissal of Senghor's universalism, given Fanon's emphasis on revolution on a national scale, and for Wilder this is a sign of an insufficiently attentive reading of Senghor. Yet there can be little doubting Fanon and Senghor's shared commitment, as articulated forcefully and poetically by Mbembe, to a truly open, global, pluriversal politics, and to the forming of a new world, one that fully embraces Africa and its future. I would argue that Achille Mbembe, and Barbara Cassin, are worthy inheritors of that powerful legacy. 


\section{References}

Büttgen, Philippe, Michèle Gendreau-Massaloux, and Xavier North eds. 2012. Les pluriels de Barbara Cassin, ou le partage des equivoques. Lormont: Le bord de l'eau.

Cassin, Barbara, Emily Apter, Jacques Lezra, Michael Wood, eds. 2014. Dictionary of Untranslatables: A Philosophical Lexicon eds. Princeton: Princeton University Press.

Cassin, Barbara ed. 2004. Vocabulaire européen des philosophies: Dictionnaire des intraduisibles. Paris: Editions du Seuil.

Cassin, Barbara. 2012. Jacques le sophiste : Lacan, logos, et psychanalyse. Paris : Epel. English translation by Michael Syrotinski. 2019. Jacques the Sophist. New York : Fordham University Press.

Cassin, Barbara. 2016. Eloge de la Traduction : Compliquer l'universel. Paris : Fayard.

Cassin, Barbara, and Wozny, Danièle, eds. 2014. Les intraduisibles du patrimoine en Afrique subsaharienne [Heritage Untranslatables in Sub-Saharan Africa]. Paris: Editions Demopolis.

Derrida, Jacques. 2002. "Faith and Knowledge", in Acts of Religion. New York: Routledge.

Fanon, Frantz. 1952 ; 2008. Black Skin, White Masks. Translated from the French by Richard Philcox. New York, Grove Press.

Fanon, Franz. 1961 ; 2004. The Wretched of the Earth. Translated from the French by Richard Philcox. New York, Grove Press.

Mbembe, Achille. 1988. Afriques indociles. Christianisme, pouvoir et état en société postcoloniale. Paris: Editions Karthala. 
Mbembe, Achille. 1993. «Écrire l'Afrique à partir d'une faille, » Politique Africaine, 51, 69-97.

Mbembe, Achille. 2005. De la Postcolonie, $2^{\text {nd }}$ edition. Paris : Editions Karthala.

Mbembe, Achille. 2001. On the Postcolony. Berkeley, CA: University of California Press.

Mbembe, Achille. 2010. Sortir de la Grande Nuit: Essai sur l'Afrique Décolonisée. Paris: La Découverte.

Mbembe, Achille. 2013. Critique de la Raison Nègre. Paris : La Découverte. English translation with an introduction by Laurent Dubois, 2017. Critique of Black Reason. Durham : Duke University Press.

Mbeme, Achille. 2016a. «Decolonizing the University : New Directions. » Arts and Humanities in Higher Eduction, 15(1), 29-45.

Mbembe, Achille. 2016b. Politiques de l'inimité. Paris : La Découverte.

Mbembe, Achille and Felwine Sarr, eds. 2017. Ecrire l'Afrique-Monde. Dakar, Jimssan.

Mudimbe, V. Y. 1988. The Invention of Africa : Gnosis, Philosophy and the Order of Knowledge. Bloomington, IN : Indiana University Press.

Mudimbe, V.Y. 1991. "Reprendre", in Africa Explores: $20^{\text {th }}$ Century African Art, Susan Vogel and Ima Ebong (eds.). New York: Center for African Art.

Nancy, Jean-Luc. 2002. La création du monde, ou la mondialisation.Paris:Galilée.

English translation by François Raffoul and David Pettigrew, 2007. The

Creation of the World, or Globalization. Albany NY: SUNY Press.

Nancy, Jean-Luc. 1991. The Inoperative Community, edited by Peter Connor.

Minneapolis: University of Minnesota Press.

Spivak, Gayatri. 1999. A Critique of Postcolonial Reason: Towards a History of the Vanishing Present. Cambridge, MA.: Harvard University Press. 
Syrotinski, Michael. 'Genealogical Misfortunes: Achilles Mbembe's (Re-)Writing of Postcolonial Africa', Paragraph 35:3, November 2012, 407-20.

Syrotinski, Michael. 2002: Singular Performances: Reinscribing the Subject in Francophone African Writing. Charlottesville: University of Virginia Press.

Thiong'o, Ngugi wa. 1986. Decolonizing the Mind: The Politics of Language in African Literature. London: Heinemann.

Wilder, Gary. 2015. Freedom Time: Negritude, Decolonization and the Future of the World. Durham, Duke University Press. 
